\title{
Yeni Bir Yaklaşım Olan Aralıklı Açlık Yöntemleri ve Sağlık Üzerine Etkileri
}

\author{
Intermittent Fasting Methods as a New Approach and Its Effects on Health
}

\author{
Ayşen Yıldırım¹, Sema Erge ${ }^{2}$
}

Geliş tarihi/Received: 13.02.2020 • Kabul tarihi/Accepted: 14.12.2020

\section{ÖZET}

Son yıllarda popüler olan aralıklı açlık yöntemleri, prevalansı tüm dünyada ve Türkiye'de giderek artan obezitenin tedavisi ve sağlık üzerinde yarattı̆̆ı düşünülen olumlu etkilerinden dolayı, dikkat çeken konular arasında yer almaktadır. Literatür verileri, alternatif gün açlık, modifiye açlık, zaman kısıtlı beslenme gibi farklı birkaç varyantı olan aralıklı açlık yöntemlerinin, vücut ağırlığı denetimi, bazı metabolik belirteçler, inflamasyon, kanser gibi bazı hastalıklar ve yaşlanma üzerinde etkili olabileceğini göstermektedir. Bahsedilen bu olumlu etkiler, uygulanan yönteme göre farklıllk gösterebilmektedir. Bu derleme yazıda, aralıklı açlık yöntemlerinin varyasyonlarından ve uygulanış biçimlerinden bahsedilmiştir. Ayrıca, bu beslenme yaklaşımlarının, sağlık üzerindeki oluşturduğu olası metabolik etkilerin ve bu etkilerin mekanizmalarının tartışılması amaçlanmıştır.

Anahtar kelimeler: Aralıklı açlık, vücut ağırlığı denetimi, inflamasyon, kanser, yaşlanma

\begin{abstract}
Intermittent fasting methods which are popular in recent years, are among the issues that attract attention due to the positive effects thought to have on health and treatment of obesity which has an increasing prevalence in worldwide and Turkey. The literature data show that intermittent fasting methods, which have several different variants such as alternative day fasting, modified fasting, and time-restricted nutrition, may be effective on some diseases such as in body weight management, some metabolic markers, inflammation, cancer and aging. These positive effects may differ depending on the method applied. In this review article, the variations of intermittent fasting methods and their application methods were mentioned. In addition, it is aimed to discuss the possible metabolic effects of these nutritional approaches on health and the mechanisms of these effects.
\end{abstract}

Keywords: Intermittent fasting, weight management, inflammation, cancer, aging

1. İletişim/Correspondence: Doğu Akdeniz Üniversitesi, Sağllk Bilimleri Fakültesi, Beslenme ve Diyetetik Bölümü, Gazimağusa, Kuzey Kubrıs

E-posta: dyt.aysenyildirim@gmail.com • ๑ https://orcid.org/0000-0003-0732-1088
2. Doğu Akdeniz Üniversitesi, Sağllk Bilimleri Fakültesi, Beslenme ve Diyetetik Bölümü, Gazimağusa, Kuzey Kibrıs • ๑ https://orcid.org/0000-0001-6674-7420 


\section{GíRiş}

Günümüzde, özellikle vücut ağırlığı kaybı ve metabolik sağlık üzerindeki etkilerinden dolayı aralıklı açlık yöntemleri, dikkat çeken konular arasında yer almaktadır (1). Dünya çapında obezite prevalansının, 1975 yılından bu yana neredeyse üç kat arttığı görülmektedir. Dünya Sağlık Örgütü 2016 verilerine göre, 18 yaş üstü 1.9 milyardan fazla yetişkin aşırı kilolu, 650 milyondan fazla yetişkin ise obezdir (2). Obezite prevalansındaki bu artış, vücut ağırlık yönetimi için farklı beslenme yaklaşımı arayışlarını da beraberinde getirmektedir. Aralıklı açlık yöntemleri de bu yeni yaklaşımlardan biridir. Açlık süreleri ve sıklığına bağlı olarak farklı aralıklı açlık uygulamalarının olduğu bilinmektedir. Aralıklı açlık yöntemlerinin vücut ağırlığı ve metabolik sağlık üzerindeki etkileri çeşitli mekanizmalarla açıklanmaktadır. Bu mekanizmalardan ilki, açlık evrelerinde keton cisimciklerinin oluşumudur. Ayrıca bu yöntemin, sirkadiyen ritim ve gastrointestinal mikrobiyota üzerindeki olumlu etkileri sayesinde, obezite ve metabolik sağlığı iyileştirebileceği düşünülmektedir $(1,3,4)$. Bu derleme makalenin amacı, aralıklı açlık yöntemlerine genel bir bakış sağlamak, sağlık üzerindeki etkilerini ve bu etkilerin fizyolojik mekanizmalarını tartışmaktır.

\section{Aralıklı Açlık Yöntemleri}

Farklı birkaç varyantı olan aralıklı açlık yöntemleri, vücut ağırlığı ve çeşitli hastalıklar üzerindeki etkileri nedeniyle ilgi gören bir yaklaşım olmuştur. Alternatif gün açlık, modifiye açlık, zaman kısıtlı beslenme ve dini ya da manevi amaçlar için uygulanan dini oruç, yaygın olarak kullanılan aralıklı açlık türlerindendir. Aralıklı açlığın uygulanma yöntemleri Tablo 1'de gösterilmiştir (1). Alternatif gün açlık, bir gün (24 saat) yiyecek ve içeceklerin istenildiği kadar tüketildiği, ertesi gün (24 saat) enerji içeren yiyecek ve içeceklerin tüketilmediği günleri kapsayan bir yöntemdir. Sıfır enerji alımındaki zorluklar nedeniyle bu yöntem, açlık günlerinde saat 12:00-14:00 arasinda enerji ihtiyacının en fazla \%25'ini tüketecek şekilde bir öğün beslenerek de uygulanabilmektedir (5). Modifiye açlık ise, kişinin haftanın beş günü yiyecek ve içeceklerin istenildiği kadar tüketildiği (ad-libitum), haftanın iki günü ise yaklaşık <500 kkal'nin altında besin tüketiminin olduğu, günlük enerji gereksinmesinin \%25'ini karşılayacak şekilde uygulanan bir yaklaşımdır (6). Bu yöntem, art arda iki gün boyunca şiddetli enerji kısıtlaması ve diğer beş gün boyunca ad libitum içeren popüler 5:2 yaklaşımının temelidir (1).

Bir diğer aralıklı açlık yöntemi ise zaman kısıtlı beslenme modelidir. $\mathrm{Bu}$ yöntem, bireylerin günün belirli saat diliminde olmak koşuluyla, kendi isteklerine bağlı olarak enerji tüketimlerine olanak tanır (7). Ne yenildiğinden daha çok, ne zaman yenildiğine odaklanan zaman kısitlı beslenme modeli, beslenme saatinin günlük sirkadiyen ritmin aktif fazıyla senkronize olarak planlanması, besin alımının günde yaklaşık 8 saat veya daha az süre yapıldığı, bunun dışındaki saatlerde besin alımının kısıtlanması temeline dayanır $(7,8)$. Bu yöntem, 16:8, 18:6 ve 20:4 olmak üzere üç varyanttan oluşur. En sık kullanılan 16:8 yöntemi, 16 saatlik açlık ve ardından 8 saatlik beslenme seansindan oluşur (9). Beslenme zamanının günün hangi saat aralığında olacağı konusunda henüz fikir birliği yoktur. Konuyla ilgili yapılan insan çalışmalarında beslenme periyotları, erken zaman kisitlı beslenme (eZKB) (saat 08:00-

Tablo 1. Farklı aralıklı açlık yöntemlerinin haftalık programına genel bakış (1)

\begin{tabular}{llllllll}
\hline & Pazartesi & Salı & Çarşamba & Perşembe & Cuma & Cumartesi & Pazar \\
\hline AGA & Açlık & Beslenme & Açlık & Beslenme & Açlık & Beslenme & Açlık \\
MA & Açlık & Açlık & Beslenme & Beslenme & Beslenme & Beslenme & Beslenme \\
ZKB & $\geq 12$ saat Açlık & $\geq 12$ saat Açlık & $\geq 12$ saat Açlık & $\geq 12$ saat Açlık & $\geq 12$ saat Açlık & $\geq 12$ saat Açlık & $\geq 12$ saat Açlık \\
\hline
\end{tabular}

AGA: Alternatif Gün Açlık, MA: Modifiye Açlı, ZKB: Zaman Kısıtlı Beslenme

*AGA ve MA'da açlık periyodunun hangi gün olacağı isteğe göre düzenlenebilmektedir. 
14:00), gün ortası zaman kısıtlı beslenme (saat 10:0017:00) ve geç zaman kısıtlı beslenme (gZKB) (saat 12:00-20:00) olmak üzere sinıflandırılmıştır (10). Yapılan çalışmalar, beslenmenin endojen sirkadiyen ritimlere en uygun şekilde ayarlanması için günün erken saatlerinde gerçekleştiği eZKB'nin, obezite ve kardiyometabolik parametreler üzerinde umut verici sonuçlar bildirmektedir (11,12). Ancak eZKB’nin bazı kişiler için sürdürülebilirliğinin daha zor olabileceği gösterilmiştir. Bu nedenle, zamanlamayı planlarken daha fazla bağlllık elde etmek ve uzun vadeli sağlık yararlarını artırmak için bir bireyin kronotipinin dikkate alınmasının önemli olabileceği vurgulanmaktadır (13).

Çeşitli aralıklı açlık yöntemlerine uyumun ne düzeyde olduğu konusunda yapılan çalışmalar sinırlıdır. Yapılan bir çalışmada, modifiye açlık ve sürekli enerji kısıtlaması diyetine bağlılık oranları karşılaştırılmış, sürekli enerji kısıtlaması uygulanan kişilerde memnuniyetsizliknedeniyleuygulanan diyetibırakma oranı \%29, modifiye açlık grubundaki kişilerde ise \%38 olmak üzere daha yüksek bulunmuştur (14). Zaman kisitlı beslenme ile ilgili Gabel et al. (15)'un yapmış olduğu çalışmada diyete bağlılık oranı \%80 olarak saptanmıştır. Varady et al. (5)'un yaptıkları çalışmada ise normal vücut ağırlığına sahip ve obez bireylere 12 hafta boyunca alternatif gün açlık diyeti uygulanmıştır. Katılımcılar, açlık günlerinde saat 12:00-14:00 arasında, ortalama 400-600 kkal olmak üzere enerji ihtiyaçlarının \%25'ini tüketmiş, diğer günlerde ise adlibitum beslenmişlerdir. Başlangıçta diyete bağlılık \%98 olarak belirlenmiş ve çalışmanın sonunda bu oranda bir düşüş saptanmamıştır.

\section{Aralıklı Açlığın Etki Mekanizmaları}

Aralıklı açlık yöntemlerinin sağlık üzerindeki etkisinin, sadece vücut ağırlığı kaybından ibaret olmadığı, bu yaklaşımın, kardiyovasküler hastalıklar, nörodejeneratif hastalıklar, inflamasyon ve kanser gibi çok çeşitli hastalıklar ile ilişkili olabileceği bildirilmiştir (16). Aralıklı açlığın sağlığı nasıl etkilediği konusu farklı mekanizmalarla açıklanmaktadır. Bu mekanizmalardan birincisi; aralıklı açlığın açlık evrelerinde keton cisimciklerinin oluşmasıdır. Glikoz ve yağ asitleri hücreler için temel enerji kaynaklarıdır. Yemekten sonra, enerji için glikoz kullanılırken, yağ adipoz dokuda trigliserit olarak depolanır. Açlık sırasında enerji ihtiyacını karşılamak için, trigliseritler yağ asitlerine ve gliserole parçalanır. Karaciğer, açlık sırasında yağ asitlerini birçok doku ve özellikle beyin için büyük bir enerji kaynağı olan keton cisimlerine dönüştürür. Tokluk sirasında keton cisimlerinin kan seviyeleri düşüktür ve açlık başladıktan sonra 8-12 saat içinde yükselir $(3,17)$. Bu yanıtın zamanlaması, aralıklı açlık yöntemlerin açlık döneminde, keton oluşumunun göstergesidir. Keton cisimleri sadece enerji kaynağ değildirler (17). Önemli hücresel yolakları etkileyen, metabolizma üzerinde önemli fonksiyonları olan, sağlığı ve yaşlanmayı etkilediği bilinen birçok protein ve molekülün [peroksizom proliferatör-aktive edilmiş reseptör $\gamma$ koaktivatör la (PGC-la) gibi] ekspresyonunu ve aktivitesini düzenleyen maddelerdir (18). Ayrıca, keton cisimlerinin beyin sağlığı, psikiyatrik ve nörodejeneratif bozukluklar ile ilişkili olan beyin türevli nörotrofik faktörün gen ekspresyonunu uyardıkları bilinmektedir (17).

Aralıklı açlığın, sağlığı etkileme mekanizmalarından bir diğeri ise sirkadiyen ritim üzerindeki etkileri ile metabolik regülasyonu sağlamasıdır. Besinler ve yemek yeme zamanlaması sirkadiyen ritmi etkilemektedir. Normal beslenme saatleri dışında, özellikle gece geç saatlerde yemek yemenin, sirkadiyen ritmi bozarak enerji dengesini etkilediği, böylece obezite, diyabet ve kardiyovasküler hastalıkların gelişimine neden olabileceği bildirilmiştir (19). Aralıklı açlık yöntemlerinin, insan sirkadiyen ritmine uygun olduğu, bu sayede obezite ve diğer kronik hastalıklara karşı koruyucu bir yaklaşım olabileceği ileri sürülmektedir (4).

Aralıklı açlık, aynı zamanda bağırsak mikrobiyal kompozisyonunu etkileyerek, sağlığı koruyucu etki gösterebilmektedir. Açlık sırasında, asetat ve laktat gibi mikrobiyota fermentasyon ürünleri artmaktadır. $\mathrm{Bu}$ ürünler, bej hücrelerde (beyaz adipoz dokudan kahverengi adipoz dokuya geçiş 
süreci) monokarboksilat taşıyıcı-1 ekspresyonunun regülasyonu ile obezite, insülin direnci ve karaciğer yağlanmasının tedavisinde yardımcı olabilmektedirler. Yapılan bir çalışmada, aralıklı açlığın, adipoz dokuda kahverengi yağ dokusunu arttırdığı ve bağırsak mikrobiyotasını değiştirerek obezite oranını azalttığı gösterilmiştir (20).

Son olarak, aralıklı açlık yöntemlerinin, yemek yeme için mevcut süreyi azalttığı, böylece toplam enerji alımını ve obezite riskini azaltabileceği öne sürülmektedir (4). Açılanan bu mekanizmalar sayesinde, aralıklı açlık yöntemlerinin vücut ağırlığı kaybının sağlanmasında, dolayısıyla obezitenin tedavisinde olumlu etkilerinin olabileceği düşünülmektedir.

Araştırma verileri, aralıklı açlık yönteminin kanser üzerinde de etkisinin olabileceğini desteklemektedir $(16,17)$.Kansertedavisindekemoterapi,radyoterapigibi hedefe yönelik tedaviyi daha da iyileştirmek için yeni terapötik stratejilerin geliştirilmesi amacıyla yapılan çalışmalar, enerji kısıtlamasının, normal hücreleri korurken otofajiyi modüle etmek ve kemoterapi, radyoterapi gibi antikanser tedavilerinin etkinliğini arttırmak için yararlı bir yaklaşım olabileceğini göstermektedir (21). Aralıklı açlık yöntemlerinin, kanser hücrelerinin enerji metabolizmasını bozduğu, büyümelerini engellediği ve onları klinik tedavilere daha duyarlı hale getirdiği düşünülmektedir (17). Altta yatan mekanizmanın ise aralıklı açlığın, insanlarda kanser oluşumuna ve ilerlemesine aracılık ettiği düşünülen insülin, sitokinler ve inflamasyonla ilişkili moleküller olan leptin ve adiponektin gibi bir dizi kanser riski biyobelirteçleri üzerindeki etkisinden kaynaklanabileceği bildirilmektedir (16). Ayrıca aralıklı açlığın, birçok kanser türünün ilerlemesini geciktirmede kemoterapi kadar etkili olabileceğini, sağlıklı hücreleri kemoterapinin aksine toksik etkilerden koruyabildiğini bildirilmiştir. Klinik çalışmalar doğrulanırsa, açlık döngülerinin, kemoterapi endikasyonu olmayan erken evre kanser hastaları veya kemoterapi alan ve nüks riski yüksek, daha ilerimaligniteleriolan hastalar için kemoterapiye bir alternatif olabileceği düşünülmektedir. Ek olarak, kemoterapi ile birlikte açlık döngüleri, hem tümör ilerlemesini geciktirerek hem de yan etkileri azaltarak ileri evre kanser hastalarının hayatta kalma süresini uzatabilmektedir (22). Ayrıca, kemirgenlerde normal yaşlanma sırasında kendiliğinden gelişen tümörlerin oluşumunu azalttığı ve kemoterapi duyarlılıklarını arttırırken birçok indüklenmiş tümör türünün büyümesini baskıladığı bildirilmiştir (17). İnsanlarda aralıklı açlık yöntemlerinin kanser üzerindeki etkisine yönelik yapılan çalışmalar sınırlıdır. Kötü huylu bir beyin tümörü türü olan glioblastomlu hastaları içeren çeşitli vaka çalışmaları, aralıklı açlığın tümör büyümesini baskılayabildiğini ve sağkalımı uzatabildiğini düşündürmektedir $(17,23)$. Groot et al. (2015)'un yapmış oldukları çalışmada, kemoterapi başlangıcından 24 saat önce ve kemoterapiden 24 saat sonra uygulanan kısa süreli açlı̆̆ın, kemoterapinin neden olduğu kemik iliği toksisitesini azalttığı ve mononükleer hücrelerinde kemoterapiye bağlı oluşan DNA hasarını azaltarak iyileşmesini hızlandırdığı gösterilmiştir (24).

Artan kanıtlar, aralıklı açlığın birtakım biyolojik yolları tetikleyerek yaşlanmayı geciktirebileceğini de düşündürmektedir. Bunlardan ilki, aralıklı açlığın, oksidatif stres ve inflamasyonun azaltılmasına yönelik oluşturduğu olumlu etkilerden kaynaklanmaktadır (25). Aralıklı açlığın yaşlanma üzerindeki diğer etkilerinin ise otofajinin uyarılması ve ketogenez sonucu oluşabileceği bilinen, yaşlanma ve yaşlanmaya bağlı hastalıklar ile ilişkilendirilen önemli bir hücresel sinyal molekülü olan Mammalian Target of Rapamycin (mTOR) yolunun inhibisyonu olabileceği bildirilmiştir (3). Bunlara ek olarak, aralıklı açlık uygulamalarının, insülin benzeri büyüme faktörü (IGF-1), dolaşımdaki glikoz ve insülin seviyelerinde yarattığı düşüşler, ayrıca IGF-1 inhibe edici proteinlerden biri olan insülin benzeri büyüme faktörü bağlayıcı proteinde (IGFBP1) yarattığı artışlardan dolayı, yaşlanmayı geciktirme üzerinde olumlu etkilerinin olabileceğini düşünülmektedir $(3,26)$.

İlerleyen yaş ve özellikle orta yaştan sonra fazla enerji alımının, inme, Alzheimer ve Parkinson hastalığı gibi nörodejeneratif hastalıkların oluşum riskini arttırdığı 
bildirilmiştir (27). Ayrıca, bu hastalıklarda meydana gelen nöron dejenerasyonunun ve ölümünün, mitokondriyal disfonksiyon, oksidatif hasar, bozulmuş lizozom fonksiyonu ve hücresel kalsiyum homeostazının düzensizliğinden kaynaklanabileceği görüşü bulunmaktadır (16). Aralıklı açlığın, hem yaşlanma, hem de farklı hücresel mekanizma yoluyla nörodejeneratif hastalıklar üzerinde olumlu etkilerinin olabileceği belirtilmektedir (28). Aralıklı açlık, mitokondriyal fonksiyonun desteklenmesi ve otofajinin, nörotrofik faktör üretiminin, antioksidan savunmaların ve DNA onarımının uyarılması dahil olmak üzere çoklu mekanizmalar yoluyla nöronal stres direncini arttırmaktadır. Ayrıca, oksidatif olarak hasar görmüş moleküllerin ve inflamasyonun azaltılması yoluyla da sinir sistemi üzerinde yararlı etkilerinin olduğu düşünülmektedir (28). Bunun yanında, Alzheimer ve Parkinson etyopatogenezinden sorumlu eksitotoksisiteyi (nöron kaybı) önleyebilen GABAerjik ( $\gamma$-aminobutirik asitile ilişkili) inhibitör nörotransmisyonu arttırdığı da bildirilmektedir (17). Nörodejeneratif hastalığı bulunan veya risk altında olan kişilerde, aralıklı açlık yöntemlerinin etkilerinin incelendiği kontrollü çalışmalar henüz bulunmamaktadır. Ancak aralıklı açlığın, Alzheimer hastalığı ve Parkinson hastalığı bulunan hayvan modellerinde nöronları koruyabileceği, hastalık süreçlerinin başlamasını ve ilerlemesini geciktirebileceğine dair güçlü kanıtlar vardır $(17,29)$.

Tüm bu mekanizmalar, aralıklı açlığın obezite ve çeşitli hastalıklar üzerinde etkili bir yaklaşım olabileceği görüşünü desteklemektedir. Ancak bu etkiler, uygulanan aralıklı açlık yönteminin türüne göre değişiklik göstermektedir (8).

\section{Alternatif Gün Açlığın Sağlık Üzerindeki Etkilerine Yönelik Çalışmalar}

Alternatif gün açlığın beden kütle indeksi 20.0$29.9 \mathrm{~kg} / \mathrm{m}^{2}$ aralığında olan bireylerde vücut ağırlık kaybı üzerine etkisinin incelendiği bir çalışmada, 32 katılımcı 12 hafta boyunca, alternatif gün açlık grubu veya kontrol grubu olmak üzere randomize edilmiştir. Çalışmanın sonunda alternatif gün açlık grubundaki katılımcıların vücut ağırlıklarının $5.2 \pm 0.9 \mathrm{~kg}$ ve vücut yağ kütlelerinin $3.6 \pm 0.7 \mathrm{~kg}$ azaldığ istatistiksel olarak anlamlı olduğu belirtilmiştir (5). Yapılan bir meta analiz çalışmasında, alternatif gün açlık ile çok düşük enerjili diyetler, vücut ağırlık kaybı, vücut yağ kütlesi ve yağsız kütle açısından karşılaştırılmış ve alternatif gün açlığın etkili bir yöntem olduğu, bazı kişilerde uyum kolaylığı sağladığı belirtilmiştir. Ayrıca yağsız kütlenin korunmasını sağlayıp, daha fazla yağ kütlesi kaybına neden olmasından dolayı tercih edilebileceği bildirilmiştir (30).

Aralıklı açlık yöntemlerinin, vücut ağırlığı denetimi üzerindeki etkilerinin yanı sira metabolizma üzerinde de etkili olabileceği bildirilmektedir. Genel olarak, bu beslenme yaklaşımının, plazma glukoz düzeyinin regülasyonu, depo glikojenin azalması, lipolizisin artması ve keton oluşumu, dolaşımda leptin düzeyinin azalması ve adiponektin seviyesinin artması gibi metabolik etkilere yol açabileceği belirtilmektedir (8). Alternatif gün açlık metabolik belirteçler üzerindeki etkilerinin araştırıldığı bir çalışmada, 8 erkek 15 gün boyunca değerlendirilmiş, çalışmanın sonunda kan glukoz seviyelerinde ve leptin seviyelerinde azalma görülürken, adinopektin seviyelerinde artış saptanmıştır (31). Horne et al. (32)'un 30 birey üzerinde yaptıkları çalışmada, alternatif gün açlığın plazma lipit profili üzerindeki etkilerine bakılmıştır. Katılımcıların trigliserit seviyelerinde azalma görülürken, yüksek yoğunluklu lipoprotein kolesterolü (HDL-C) ve düşük yoğunluklu lipoprotein kolesterol (LDL-C) seviyelerinin arttığ1 tespit edilmiştir. Astım tanısı almış obez bireylere 8 hafta boyunca alternatif gün açlık yöntemi ile diyet uygulatılmış; vücut ağırlıklarında (ortalama $\% 8$ oraninda), inflamasyon ve oksidatif stres belirteçlerinde azalmalar, aynı zamanda semptom ve solunum fonksiyonlarında da iyileşmeler saptanmıştır (33). Non-alkolik yağlı karaciğer hastalığı olanlarda alternatif gün açlık uygulamasının vücut ağırlığı ve lipid profili üzerindeki etkilerinin araştırıldığı bir çalışmada, 271 katılımcı alternatif gün açlık, zaman kısitlı beslenme ve kontrol grubu olmak üzere 3 gruba 
randomize edilmiştir. On iki hafta süren çalışmanın sonunda vücut ağırlığının, zaman kısıtlı beslenme ve alternatif gün açlık grubunda, kontrol grubuna kıyasla önemli ölçüde azaldığı saptanmıştır. Dördüncü haftanın sonunda yapılan ölçümlerde, hem zaman kısıtlı beslenme grubunda, hem de alternatif gün açlık grubunda vücut yağ kütlesinin önemli ölçüde azaldığı, 12. haftanın sonunda alternatif açlık uygulamasının vücut yağ kütlesinde daha fazla azalmaya yol açtığı belirlenmiştir. Aynı zamanda alternatif gün açlı̆̆ın, toplam kolesterol seviyesinde daha fazla düşüşe neden olduğu görülmüştür. Ancak yağsız kütle, HDL-C, LDL-C, açlık insülin ve glikoz düzeylerinde ayrıca, sistolik ve diyastolik kan basıncındaki değişikliklerin gruplar arasında farklılık göstermediği saptanmıştır (34).

\section{Modifiye Açlığın Sağlık Üzerindeki Etkilerine Yönelik Çalışmalar}

Modifiye açlık yönteminin vücut ağırlığı kaybındaki etkisinin incelendiği bir araştırmada, fazla kilolu ve obez kadınlara 6 hafta boyunca modifiye açlık yöntemi uygulanmıştır. Açlık günlerinde tüm katılımcılara enerji ihtiyaçlarının \%25-30'unu karşllayacak kadar bir enerji, diğer günlerde ise 1700-1800 kkal enerji içeren bir beslenme programı uygulatılmıştır. Araştırmanın sonunda katılımcıların vücut ağırlığı (yaklaşık \%7.1) ve bel çevrelerinde (yaklaşık \%5.7) istatistiksel olarak anlamlı bir azalma saptanmıştır. Çalışmada aynı zamanda uygulanan modifiye açlık yönteminin kan lipit seviyeleri üzerindeki etkisine bakılmış, ancak istatistiksel olarak anlamlı bir değişiklik yaratmadığı tespit edilmiştir (35). Modifiye açlık yönteminin bazı biyobelirteçler üzerindeki etkilerini inceleyen araştırmalar çelişkili sonuçlar vermektedir. Fazla kilolu ve obez 107 kadın üzerinde yapılan bir başka çalışmada ise 6 haftalık modifiye açlık diyeti uygulaması ile insülin düzeylerinde azalma saptanırken, kan glikoz, LDL-C ve HDL-C, trigliserit, C-reaktif protein (CRP), adinopektin ve leptin seviyelerinde istatistiksel olarak anlamlı bir fark gözlenmemiştir (36). Bunun aksine, Varady et al. (37)’un 8 haftalık modifiye açlığın total kolesterol,
LDL-C ve trigliserit seviyelerinde istatistiksel olarak anlamlı bir azalmaya neden olarak, kalp damar hastalıklarına karşı koruyucu etki yaratabileceğini belirtmişlerdir.

\section{Zaman Kısıtlı Beslenmenin Sağlık Üzerindeki Etkilerine Yönelik Çalışmalar}

Zaman kısıtlı beslenmenin, günün erken periyoduna mı (saat 08:00-14:00) yoksa geç periyoduna mı (saat 12:00-20:00) ayarlanması konusunda görüş birliği yoktur. Hutchison et al. (11)'un tip 2 diyabet riski altındaki obez erkekler üzerinde yapmış oldukları çalışmada, geç zaman kısıtlı beslenme ve erken zaman kısıtlı beslenme karşılaştırılmış, erken zaman kısıtlı beslenmenin açlık glikoz düzeyini önemli ölçüde düşürdüğü saptanmıştır. Yine erken zaman kısıtlı beslenmenin etkilerinin araştırıldığı bir çalışmada, obez ve prediyabeti olan katılımcılar müdahale ve kontrol gurubu olmak üzere iki gruba randomize edilmiştir. Müdahale grubuna, 5 hafta süreyle 6 saatlik (saat 08:00-14:00) beslenme periyodu uygulanırken, kontrol grubuna sabah 08:00-akşam 20:00 olmak üzere 12 saatlik bir beslenme periyodu uygulanmıştır. Çalışmanın sonunda erken zaman kısitlı beslenme grubunda, kontrol grubuna kıyasla insülin duyarlılığında iyileşme, kan basıncı ve plazma trigliserit seviyelerinde, oksidatif stres belirteçlerinde ve geceleri yaşanan açlık ataklarında önemli düşüşler gözlenmiştir (12).

Zaman kısıtlı beslenmenin sağlık üzerindeki etkilerinin uygulanan varyantına göre değişiklik gösterdiği bildirilmiştir (10). Obez katılımcılarda yapılan bir çalışmada, 4 saatlik ve 6 saatlik zaman kısitlı beslenmenin vücut kompozisyonu ve metabolik hastalık risk faktörleri üzerindeki etkileri karşılaştırılmıştır. Sekiz hafta süren çalışmanın sonunda vücut ağırlığının her iki grupta benzer şekilde azaldığı saptanmıştır. Dört saatlik ve 6 saatlik zaman kısıtlı beslenme gruplarında kontrollere göre yağ kütlesi, kan basıncı ve insülin duyarlılığının da benzer şekilde azaldığı saptanmıştır (38). Obez kişilerde 12 hafta süre ile yapılan bir başka çalışmada ise 6 saat ve 8 saatlik zaman kısıtlı beslenme kıyaslanmış, 
6 saatlik zaman kısıtlı beslenme grubunda yağsız vücut kütle kaybının daha fazla olduğu belirlenmiştir (39). Zaman kısıtlı beslenmenin insanlar üzerindeki etkilerinin araştırıldığı çalışmaların meta analizinde, bu beslenme modelinin, toplam kolesterol, trigliserit, glukoz, insülin, IL-6, TNF-a düzeylerinde ve insülin duyarlılığında iyileşmelere neden olduğu sonucuna varılmıştır (40).

\section{SONUÇ VE ÖNERILER}

$\mathrm{Bu}$ derleme makalede; aralıklı açlık yöntemlerinin obezite ve bazı hastalıklar üzerindeki etkileri incelenmiştir. Genel olarak, yapılan araştırmalar, aralıklı açlığın sağlıklı, normal vücut ağırlığına sahip, fazla kilolu veya obez yetişkinlerde fiziksel olarak zararlı olmadığını, hatta vücut ağırlığı kaybı ve bazı metabolik belirteçler üzerinde olumlu etkilerinin olabileceğini gösterse de hangi özellikteki kişilerin bu yeme düzenine uyum sağlayabileceği ile ilgili kriterler ve açlık dönemlerinin psikolojik etkilerine (kısıtlama sırasında ve sonrasında nasıl hissedildiği, yoksunluk hissine neden olup olmadığı vb.) ilişkin kanıtlar yetersizdir. Bazı kişilerin alternatif günlerde enerji kısıtlamasını sürekli kısıtlamadan daha kolay ve cazip bulacağı da dikkate alınmalıdır. Önemli bir soru ise düzenli olarak aralıklı açlık yöntemlerinin benimsemenin uygulanabilir ve sürdürülebilir bir strateji olup olmadığı ve uzun vadede etkilerinin ne olduğudur. Özellikle 500 kkal gibi enerjisi çok düşük diyetin çok uzun süre sürdürülmemesi ayrıca, sık kontroller ile diyetisyen gözetimi altında uygulanması sağlık risklerinin azaltılabilmesi açısından önemli ve gereklidir. Kesin bir görüşün olmadığı ve araştırılması gereken bir diğer konu ise aralıklı açlığın vücut ağırlığı kaybı olmadan da sağlık üzerindeki olumlu etkilerinin olup olmayacağıdır.

Sonuç olarak elde edilen veriler, aralıklı açlık yöntemlerinin, haftanın, günün veya gecenin belirli saatlerinde yememeyi veya çok az yemeyi güvenle tolere edebilen insanlar için vücut ağırlığı kaybı sağlamak ve metabolik sağlığı geliştirmek için umut verici bir yaklaşım olabileceğini düşündürmektedir.
Ancak, yapılan çalışmaların çoğunun küçük örneklemli, kısa süre takipli ve genel olarak sağlıklı insanlar üzerinde yapılmış olduğu göz önünde bulundurulmalıdır. $\mathrm{Bu}$ nedenle, aralıklı açlık yöntemlerinin, hastalık durumunda ve uzun vadede metabolik etkilerini inceleyen daha fazla randomize kontrollü çalışmalara ihtiyaç duyulmaktadır.

Çıkar çatışması - Conflict of interest: Yazarlar çıkar çatışması olmadığını beyan ederler. - The authors declare that they have no conflict of interest.

\section{KAYNAKLAR}

1. Patterson RE, LaCroix AZ, Natarajan L, Senger CM, Martinez E, Villasenor A, et al. Intermittent fasting and human metabolic health. J Acad Nutr Diet. 2015;115(8):1203-12.

2. World Healh Organization (WHO). Obesity and overweight, 2018. Available at: https://www.who.int/ news-room/fact-sheets/detail/obesity-and-overweight. Accessed: November 9,2019.

3. Longo VD, Mattson MP. Fasting: Molecular mechanisms and clinical applications. Cell Metab. 2014;19:181-92.

4. Patterson RE, Sears DD. Metabolic effects of intermittent fasting. Annu Rev Nutr. 2017;37:371-93.

5. Varady K. Bhutani A, Klempel S, Kroeger MC, Trepanowski MC, Haus JF, et al. Alternate day fasting for weight loss in normal weight and overweight subjects: A randomized controlled trial, Nutr J. 2013;12(1):146-53.

6. Varady KA. Intermittent versus daily calorie restriction: which diet regimen is more effective for weight loss? Obes Rev. 2011;12(7):593-601.

7. Upadhyay A, Anjum B, Godbole NM, Rajak S, Shukla P, Tiwari S, et al. Time-restricted feeding reduces highfat diet associated placental inflammation and limits adverse effects on fetal organ development. Biochem Biophys Res Commun. 2019;514(2):415-21.

8. Akpınar S, Akbulut G. Aralıklı açlık diyetlerinin ağırlık denetimi ve sağlık çıktıları üzerindeki etkisi. Süleyman Demirel Üniversitesi Sağllk Bilimleri Dergisi. 2019;10(2):177-83.

9. Malinowski B, Zalewska K, Wesierska A, Sokolowska MM, Socha M, Liczner G, et al. Intermittent fasting in cardiovascular disorders-An overview. Nutrients. 2019;11(3):673.

10. Regmi P, Heilborn LK. Time-Restricted Eating: Benefits, mechanisms, and challenges in translation. Science. 2020;23(6).

11. Hutchison AT, Regmi P, Manoogian ENC, Fleischer JG, Wittert GA, Panda S, et al. Time-restricted feeding 
improves glucose tolerance in men at risk for type 2 diabetes: A randomized crossover trial. Obesity (Silver Spring, Md.). 2019;27(5):724-32.

12. Sutton EF, Beyl R, Early KS, Cefalu WT, Ravussin E, Peterson CM. Early time-restricted feeding improves insulin sensitivity, blood pressure, and oxidative stress even without weight loss in men with prediabetes. Cell Metabolism. 2018;27(6):1212-21.

13. Qoeiroz JN, Macedo RCO, Tinsley GM, Oliveira AR. Timerestricted eating and circadian rhythms: the biological clock is ticking. Crit Rev Food Sci. 2020;14:1-13.

14. Trepanowski JF, Kroeger CM, Barnosky A, Klempel M, Bhutani S, Hoddy KK, et al. Effects of alternate-day fasting or daily calorie restriction on body composition, fat distribution, and circulating adipokines: Secondary analysis of a randomized controlled trial. Clin. Nutr. 2018;37:1871-8.

15. Gabel K, Hoddy KK, Haggerty N, Song J, Kroeger CM, Trepanowski JF, et al. Effects of 8-hour time restricted feeding on body weight and metabolic disease risk factors in obese adults: A pilot study. Nutr. Healty Aging. 2018;4:345-53.

16. Mattson MP, Longo VD, Harvie M. Impact of intermittent fasting on health and disease processes. Ageing Res Rev 2017;39:46-58.

17. Cabo R, Mattson MP. Effects of intermittent fasting on health, aging, and disease. N Engl J Med. 2019;381:254151.

18. Newman JC, Verdin E. $\beta$-Hydroxybutyrate: a signaling metabolite. Annu Rev Nutr. 2017;37:51-76.

19. Boerge HL, Bhatti MZ, St-Onge MP. Circadian rhythms and meal timing: impact on energy balance and body weight. Curr Opin Biotech. 2021;70:1-6.

20. Li G, Xie C, Lu S, et al. Intermittent fasting promotes white adipose browning and decreases obesity by shaping the gut microbiota. Cell Metab. 2017;26:672-85.

21. Antunes F, Erustes AG, Costa AJ, Nascimento AC, Bincoletto C, Ureshino RP, et al. Autophagy and intermittent fasting: the connection for cancer therapy? Clinics 2018;73(1):814.

22. Raffaghello L, Lee C, Safdie FM, Wei M, Madia F, Bianchi $\mathrm{G}$, et al. Starvation-dependent differential stress resistance protects normal but not cancer cells against high-dose chemotherapy. Proc Natl Acad Sci U S A. 2018;105:8215-20.

23. Nencioni A, Caffa I, Cortellino S, Longo VD. Fasting and cancer: molecular mechanisms and clinical application. Nat Rev Cancer. 2018;18:707-19.

24. Groot S, Vreeswijk MPG, Welters MJP, Gravesteijn G, Boei JWA, Jochems A, et al. The effects of short-term fasting on tolerance to (neo) adjuvant chemotherapy in HER2-negative breast cancer patients: a randomized pilot study. BMC Cancer. 2015;15:652.

25. Anton S, Leewenburgh C. Fasting or caloric restriction for Healthy Aging. Exp Garentol. 2013;48(10):1003-5.

26. Thissen JP, Ketelslegers JM, Underwood LE. Nutritional regulation of the insulin-like growth factors Endocr Rev. 1994;15:80-101.

27. Hou Y, Dan X, Babbar M, Wei Y, Hasselbalch SG, Croteau DL, el al. Ageing as a risk factor for neurodegenerative disease. Nat Rev Neurol. 2019;15:565-81.

28. Mattson MP. Energy intake and exercise as detrminants of brain health and vulnerability to injury and disease. Cell Metab. 2012;16:706-22.

29. Mattson MP, Moehl K, Ghena N, Schmaedick M, Cheng A. Intermittent metabolic switching, neuroplasticity and brain health. Nat Rev Neurosci. 2018;19:63-80.

30. Alhamdan BA, Garcia-Alvarez A, Alzahrnai AH, Karanxha J, Stretchberry DR, Contera KJ, et al. Alternateday versus daily energy restriction diets: which is more effective for weight loss? A systematic review and metaanalysis. Obes Sci Pract. 2016;293-302.

31. Halberg N, Henriksen M, Soderhamn N, Stallknecht B, Ploug T, et al. Effect of intermittent fasting and refeeding on insulin action in healthy men. J Appl Physiol. 2005;99:2128-36.

32. Horne BD, Muhlestein JB, Lappe DL, May HT, Carlquist JF, et al. Randomized cross-over trial of short-term water-only fasting: metabolic and cardiovascular consequences. Nutr Metab Cardiovasc Dis. 2013:23:10507.

33. Johnson JB, Summer W, Cutler RG, et al. Alternate day calorie restriction improves clinical findings and reduces markers of oxidative stress and inflammation in overweight adults with moderate asthma. Free Radic Biol Med. 2007;42:665-74.

34. Cai H, Qin YL, Shi ZY, Chen JH, Zeng MJ, Zhou W, et al. Effects of alternate-day fasting on body weight and dyslipidaemia in patients with non-alcoholic fatty liver disease: A randomised controlled trial. BMC Gastroenterol. 2019;19:219.

35. Eshghinia S, Mohammadzadeh F. The effects of modified alternate-day fasting diet on weight loss and CAD risk factors in overweight and obese women. J Diabetes Metab Disord. 2013;12:1-4.

36. Harvie MN, Pegington M, Mattson MP, Frystyk J, Dillon B, Evans G, et al. The effects of intermittent or continuous energy restriction on weight loss and metabolic disease risk markers: a randomized trial in young overweight women. Int J Obes, 2011;35(5):7. 
37. Varady KA, Bhutani S, Church EC, Klempel MC. Shortterm modified alternate-day fasting: a novel dietary strategy for weight loss and cardioprotection in obese adults. Am J Clin Nutr. 2009;90(5):1138-43.

38. Cienfeugos S, Gabel K, Kalam F, Ezpeleta M, Pavlou V. Weight loss efficacy of 4-hour versus 6-hour time restricted feeding in adults with obesity. Curr Dev Nutr. 2020;4(2):584.
39. Gabel K, Cienfeuegos S, Kalam F, Ezpeleta N, Varady KA. The effect of 6 - $\mathrm{h}$ and 8-h time restricted feeding on body weight, glucoregulatory factors, IGF-1 and IGFBP-3 in adults with obesity. Curr Dev Nutr. 2020;4(2):324.

40. Rothschild J, Hoddy KK, Jambazian P, Varady KA. Time restricted feeding and risk of metabolic disease: a review of human and animal studies. Nutr Rev. 2014;72(5):30818. 